Рад примљен: 14. 8. 2017.

Рад прихваћен: 16. 3. 2018.

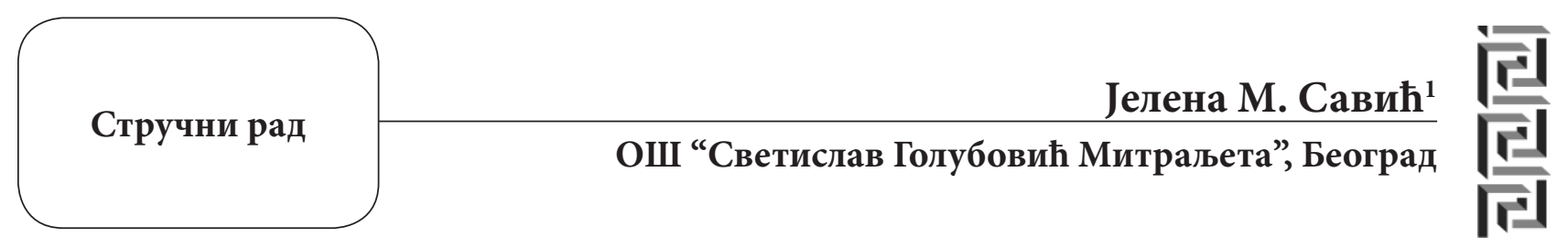

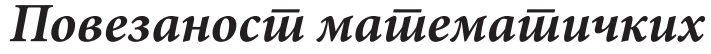 и музичких саgржаја у нижим разреgима основне школе
}

\begin{abstract}
Резиме: Саяржај раgа усмерен је на уйврђиване ефикасностии ексиеримениталнот ирроірама заснованої на йовезиваюу матиематиччких и музичких саgржаја раgи усиетнијеі савлаgаваюа іраяива у оквиру обају ирреgметиа у нижим разреgима основне школе. У савре-

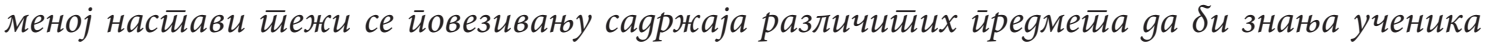

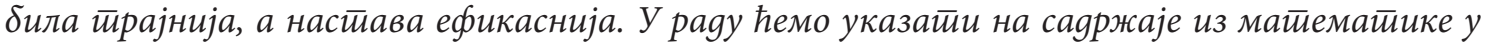
којима је могуућа имйлеменитација саgржаја из музичке кулииуре и обрнуйо раgи йобољиаға

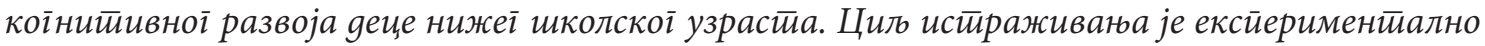
исиитииваюе и йроучаваюе ефекайа настиявноі йрисииуй у коме се йовезују саяржаји из маиемайике и музичке кулитуре. Коришћена је ексиерименйална метиоgа на основу које смо gо-

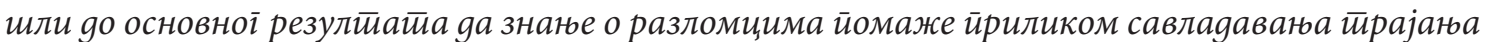
йонова (и обрнуйо). Уочено је и слабо йознаватье основних елеменатиа музичке йисменостии коg ученика, сииоїа истичемо йоиенцијалну мотиивацију за юихово учеюе ирименом оних матемеатичких саяржаја који су сушииински иовезани са одређеним музичким саяржајима.
\end{abstract}

Кључне речи: нижи разреgи основне школе, насйава матемайике, насйава музичке кулитуре, йовезиваюе матемматичких и музичких саgржаја.

Увод

Како се у савременој настави све више говори о корелацији ${ }^{2}$ садржаја различитих настав-

1 jelenasavic222@gmail.com

2 Корелација у настави - функционално повезивање и усклађивање наставних садржаја из различитих предмета који су слични или се међусобно допуњују (Stojanović, 2014).

них предмета ради ефикасније и занимљивије наставе (Šulentić Begić, Begić, 2013; Hurić, 2014; Biočić, 2015), ми ћемо указати на поједине садржаје из математике и музичке културе који се могу повезати у нижим разредима основне школе. Овој тематици није посвећено довољно пажње у стручној и научној литератури код нас, што се тиче разредне наставе, стога овим радом Copyright $\odot 2018$ by the authors, licensee Teacher Education Faculty University of Belgrade, SERBIA.

This is an open access article distributed under the terms of the Creative Commons Attribution License (CC BY 4.0) (https://creativecommons.org/licenses/by/4.0/), which permits unrestricted use, distribution, and reproduction in any medium, provided the original paper is accurately cited. 
желимо и да отворимо питања за даља истраживања у овом смеру. Намера нам је била да испитамо ефекте наставног приступа у ком се повезују математички и музички садржаји. Спровели смо експериментално истраживање на основу чега смо дошли до закључка да ученици који су савладали разломке лакше савладавају тонска трајања и њихове односе, и обрнуто. С обзиром на то да су ученици показали слабо знање из музичке писмености на иницијалном тесту знања у оквиру нашег истраживања, желимо да истакнемо да учитељи могу да оспособе ученике за музичку писменост тако што ће повезати одређене математичке садржаје на оним местима у музичкој култури где је то смислено и корисно и тиме допринети лакшем савладавању музичких садржаја.

\section{Теоријски приступ}

Узајамна повезаност различитих наставних предмета доприноси сврсисходнијој, квалитетнијој, смисленијој и занимљивијој настави (Diefes-Dux et al., 2013) и ученицима бива лакше да увиде да предмети које уче нису неповезани. Веома је битно да ученици повезују идеје и да притом имају наставникову помоћ. У супротном, како Ђокић истиче, ученици би учили изоловане појмове без препознавања општих принципа који су битни за одређена подручја у настави (Đokić, 2007). Један од узрока неповезивања садржаја различитих предмета је управо међусобна неусклађеност, то јест несинхронизованост наставних планова и програма различитих наставних предмета, стога би требало обратити пажњу на тај сегмент и то покушати променити у систему образовно-васпитног рада тако да заживи настава у којој би појмови и садржаји из различитих наставних предмета требало да се виде повезано.

Обема областима, и математици и музици уопште, заједничко је то што имају тенденцију ка симетрији, хармонији, поретку, обухватању структура и образаца, апстрактном мишљењу, креативности, неопходност когнитивних операција којима претходи стварање представа о појмовима који су мање или више апстрактни (Savić, 2016), а истиче се и да математика и музика почивају на истим принципима (David, 1995; Scripp, 2000; Shah, 2010; Whitwell, 2011; Gnjidić, 2014). Споменули смо креативност, која се сматра за главну одлику музике. Са друге стране, распрострањено је мишљење да математика и креативност немају додирних тачака. Међутим, суштина математике управо и јесте у креативном мишљењу, а не само у долажењу до тачног резултата. С обзиром на то да се под креативношћу подразумева стварање нечег што је ново или оригинално, веома је битно неговати истраживачки дух код ученика, да на тај начин долазе до решења неког проблема, успут развијајући своје мисаоне потенцијале (Dejić, Mihajlović, 2014).

Потврђено је да успех у математици расте са дужином трајања активног слушања музике (Maričić, Ćalić, 2015). Тако се у првом разреду песма може искористити као активност за развијање менталних представа о појму броја (Maričić, Ćalić, 2015), где ученици визуализују текст, при чему се ствара добра основа за стварање реалног контекста у вези са скуповима.

Исто тако песма може послужити и као активност при усвајању релација положаја и просторне оријентације, такође у првом разреду (Maričić, Ćalić, 2015; Grandin et al., 1998; Kells, 2008), тако што ученици могу да се крећу у складу са захтевима из текста (три улево, два удесно и слично).

у другом разреду може се утврђивати знање о рачунским операцијама и подстицати музичко стваралаштво и креативност смишљањем бројева и рачунских операција као строфе које се римују и у складу су са мелодијом песме „Рачунање“ (Stojanović, Vasiljević, 2013). 
Кроз певање и извођење корака игре уз песме, при чему се као симболи покрета користе геометријске фигуре, где правоугаоник $(-\mathbf{-})$ симболише корак у месту, а троуглови ( ) корак удесно и $(\bullet)$ корак улево, ученици везују симболе (геометријске фигуре) за покрет, чија комбинација представља бочно кретање у оквиру којег се покрет може повезати са дужи и тако доћи до форме песме и њеног лакшег памћења (Jović Miletić, 2008). Дакле, ученици кроз певање и извођење корака игре уз песме могу формирати неке од математичких појмова и притом бивају мотивисанији за рад и само усвајање градива.

Ставићемо акценат на садржаје који су фундаментално повезани и који могу смислено и суштински да се повежу, а то су разломци и трајање тонова (Barry, 2008; Andrić, Spasojević, 2012). Да учење математике и музике даје позитивне резултате, показало је и истраживање Кори и сарадника (Courey et al., 2012), где су ученици који су показали слабо знање из разломака на претесту постигли одличне резултате након примене повезивања разломака са музиком. На западу САД, у калифорнијској школи, користи се ритам за учење разломака, што је допринело знатно бољим резултатима ученика на математичким тестовима. Оваква повезаност посебно доприноси побољшању постигнућа код ученика који слабије уче, јер на овај начин настава бива мотивишућа, изазовнија и другачија од оне на коју су навикли (Johnson, Edelson, 2003). Код разломака једно цело се дели на половине, четвртине, осмине. Исто важи и у музици, цела нота има своје одређено трајање и када се подели на половине, те две половине трајаће заједно као цела нота; што је једнако трајању четири четвртине и осам осмина ноте. У настави музичке културе, почевши од трећег разреда, ради се на поставци музичке писмености и ученици тада почињу да уче да певају и свирају песме из нотног текста, док у првом и другом разреду уче песме по слуху. Из математике се такође у трећем разреду уче разломци облика $\frac{1}{\mathrm{a}}(\mathrm{a} \leq 10)$ (Nastavni program obrazovanja $i$ vaspitanja za treći razred osnovnog obrazovanja i vaspitanja, 2012), стога, уколико се прво уче разломци, они могу помоћи усвајању трајања тонова и обрнуто. У питању су разломци $\frac{1}{2}, \frac{1}{4}$ и $\frac{1}{8}$, док се у музици нотне вредногти истих трајања пзначавају на следећи начин: - (половина ноте), • (четвртина ноте) и • (осмина ноте). Уколико су ученици усвојили знање о разломцима, лакше ће усвојити знање о трајањима тонова, где ће знати да, на пример, половина ноте траје дупло дуже од четвртине ноте (зато што је половина једнака двема четвртинама), осмина дупло краће од четвртине, да су једна и још једна осмина ноте једнаке једној четвртини ноте. Ученици на овај начин утврђују међусобне односе трајања тонова повезивањем са разломцима који имају еквивалентну вредност (Culek, 2015). Овако се негује ученичко критичко и логичко мишљење, што доводи до трајнијих и целовитијих знања (Barry, 2008).

\section{Методолошки оквир истраживања}

Преgмети истраживања је методичка ефикасност модела учења где се повезују садржаји из математике и музичке културе. Циљ истраживања је експериментално испитивање ефеката наставног приступа у ком се повезују математички и музички садржаји. Заgаци истраживања су следећи:

1. Утврдити уједначеност контролне и експерименталне групе по знању на иницијалном тесту.

2. Испитати да ли постоји утицај експерименталног модела на математичка знања, као и на музичка знања на финалном тесту.

3. Испитати да ли постоји утицај експерименталног модела у задацима који 
захтевају повезивање математике и музичке културе на финалном тесту.

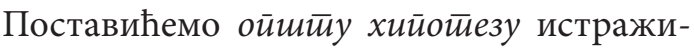
вања да постоји статистички значајна разлика у постигнућу ученика контролне и експерименталне групе када је у питању повезивање садржаја математике и музичке културе.

Мейоg и узорак истираживаға. Применили смо експерименталну методу, рад са паралелним групама, а као инструмент истраживања коришћен је тест знања - иницијални (Прилог 1) и финални (Прилог 2). Узорак истраживања чинило је сто деветнаест ученика четвртог разреда (педесет и девет ученика у контролној групи и шездесет ученика у експерименталној) Основне школе „Светислав Голубовић Митраљета“ из Батајнице. Одржали смо четири часа експерименталног програма (један час недељно), на којима смо повезивали разломке са трајањима тонова, док нам је дуж била модел за објашњавање тактова кроз различите типове задатака. За то време, контролна група је обрађивала исте садржаје, али без повезивања. Пре експерименталног програма дат је иницијални тест знања у оквиру ког су математички задаци 1, 2. и 7, задаци из музичке културе 3,4 , 5. и 6, а 8. задатак је захтевао повезивање садржаја ових двају наставних предмета. У финалном тесту знања, који је дат након експерименталног програма, математички задаци су 1, 3. и 4, задаци из музичке културе су 2, 5. и 6, а задаци са повезивањем садржаја су 7, 8. и 9. Напоменули бисмо да су, за разлику од иницијалног теста знања, у коме је један задатак захтевао повезивање садржаја, у финалном тесту знања дата три задатка са повезивањем садржаја. Како бисмо упоредили постигнућа ученика контролне и експерименталне групе и утврдили да ли постоји статистичка значајност, користили смо т-тест.

\section{Резултати и дискусија}

За уједначавање група послужили су нам резултати иницијалног теста (Прилог 1), након чега смо т-тестом утврдили да не постоји статистички значајна разлика у постигнућу ученика контролне и експерименталне групе $(\mathrm{t}=1,92$, $\mathrm{df}=109, \mathrm{p}<0.01)$. На овај начин дошли смо до закључка да су групе уједначене према предзнању ученика, и то са сигурношћу од 99\%, јер је р вредност мања од 0.01. Што се тиче задатака из математике у иницијалном тесту $(1,2$. и 7. задатак, Прилог 1), утврђено је да нема статистички значајне разлике, то јест да су ученици контролне и експерименталне групе прилично уједначених знања $(\mathrm{t}=0,18, \mathrm{df}=109, \mathrm{p}<0.01)$. Успех ученика контролне и експерименталне групе из музичких задатака $(3,4,5$. и 6. задатак, Прилог 1) такође се не разликује, тако да су и у овом случају групе уједначене према знању $(\mathrm{t}=1,07, \mathrm{df}=109$, $\mathrm{p}<0.01)$.

Ефекат примењеног модела посматрали смо кроз ефекат модела на математичка знања о разломцима, знања из музике и могућност повезивања математичког и музичког знања. Што се тиче ефекта на математичка знања $(1,3$. и 4. задатак, Прилог 2), контролна и експериментална група су уједначене $(\mathrm{t}=1,2, \mathrm{df}=111, \mathrm{p}<0.01)$ када се гледају укупни резултати, што није случај и са ефектом на музичка знања $(2,5$. и 6. задатак, Прилог 2), у којима је експериментална група била знатно боља у односу на контролну групу $(\mathrm{t}=3,85, \mathrm{df}=111, \mathrm{p}>0.01)$ (Табела 1). Заслуге бисмо приписали новом приступу повезивања садржаја, на ком се додатно радило на усвајању и проширивању знања из музичке културе имплементацијом математичких садржаја, јер су ученици на иницијалном тесту из музичке културе показали слабо знање из тонских трајања и њима одговарајућих нотних пауза, као и из комбинације нотних вредности у оквиру задате врсте такта (мере) и поретка нота. 


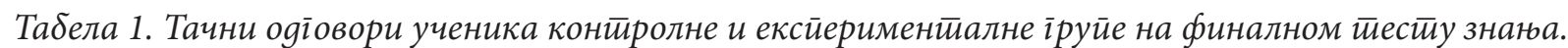

\begin{tabular}{lccccccc}
\hline & \multicolumn{2}{c}{ Редни број математичких задатака } & \multicolumn{3}{c}{ Редни број музичких задатака } \\
\cline { 2 - 7 } & 1. & 3. & 4. & 2. & 5. & 6. \\
\hline $\begin{array}{l}\text { Контролна } \\
\text { група }\end{array}$ & $\mathrm{N}$ & 23 & 5 & 1 & 2 & 12 & 2 \\
\hline $\begin{array}{l}\text { Експериментална } \mathrm{N} \\
\begin{array}{l}\text { група } \\
\mathrm{nyyyyyy}\end{array}\end{array}$ & $\mathrm{f}$ & $56,1 \%$ & $8,9 \%$ & $1,8 \%$ & $3,6 \%$ & $21,4 \%$ & $3,6 \%$ \\
\hline
\end{tabular}

$\mathrm{N}$ - број ученика; $\mathrm{f}$ - проценат

На основу добијене аритметичке средине и стандардне девијације за контролну (АС $=10,55$, $\left.\mathrm{CД}=4,66^{3}\right)$ и експерименталну групу $(\mathrm{AC}=18,19$, $\mathrm{CД}=8,54)$ на финалном тесту, израчунали смо вредност т-теста $(\mathrm{t}=5,88, \mathrm{df}=111, \mathrm{p}>0.1)$, која указује на то да постоји статистички значајна разлика у постигнућу ученика који су прошли експериментални програм (експериментална група) у односу на ученике који нису прошли програм (контролна група).

Обратићемо пажњу на задатке из финалног теста знања који су захтевали повезивање садржаја. Дискутујмо о другом задатку (Прилог 2), у ком се захтевало да се повежу једнака трајања тонова. На први поглед, рекло би се да се овде тражи музичко знање, међутим, овај задатак може врло једноставно да се реши тако што ће се искористити знање о разломцима. Један од начина за решавање био би да се испод сваке нотне вредности напише разломак који јој одговара (на пример, разломак $\frac{1}{8}$ одговара осмини ноте •), а додатно се може нацртати и правоугаоник који се дели на половине, четвртине, осмине, на основу чега се стиче увид у то које нотне вредности су једнаке помоћу разломака (и скице правоугаоника). У контролној групи је само двоје ученика (3,6 \%) одговорило тачно, а у експерименталној групи тридесет троје (57,9 \%), стога је за овај задатак израчуната вредност ттеста $(\mathrm{t}=5,27, \mathrm{df}=111, \mathrm{p}>0.01)$, на основу чега се

3 АC - аритметичка средина; СД - стандардна девијација. види да је експериментална група знатно боље урадила задатак од контролне групе. Најчешћа грешка коп контролне групе је била та да су повезивали .. и . . (две осмине и две четвртине) мислећи да су једнаког трајања (Слика 5).

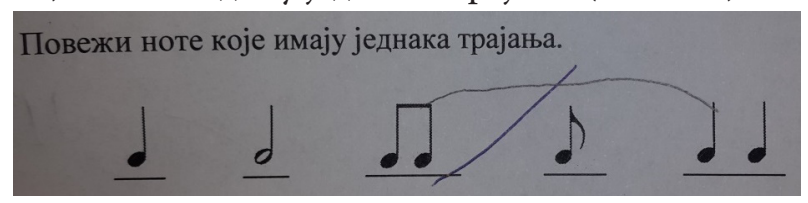

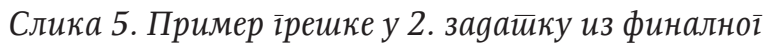
йестиа знања.

Двадесет пет ученика (44,6\%) дало је такав одговор, што указује на недовољно познавање елементарних нотних вредности. Можемо да кажемо да ученици могу успешније да реше задатке уколико се ради на одређеним задацима у музичкој писмености са убацивањем садржаја из математике.

Дискутујмо и о седмом задатку у финалном тесту (Прилог 2). Захтевао је повезивање разломака и трајања тонова, о чему је било речи у теоријском делу рада. Седамнаест ученика $(30,4 \%)$ у контролној групи и четрдесет $(70,2 \%)$ у експерименталној групи је одговорило тачно на овај захтев (Табела 3). Иако смо израчунали да постоји статистички значајна разлика у постигнућу ученика у корист експерименталне групе $(\mathrm{t}=2,57, \mathrm{df}=111, \mathrm{p}>0.05)$, што тврдимо са 95\% сигурности, јер је р вредност већа од 0.05, сматрамо да резултат од 30\% ученика контрол- 
не групе није занемарљив и да ученици знају да је четвртина ноте еквивалентна разломку $\frac{1}{4}$. Издвојили бисмо занимљиво решење једног ученика из контролне групе који је као еквивалент за $\frac{1}{4}$ нацртао ноту .. (две осмине) (Слика 6), што је једнако једној четвртини.

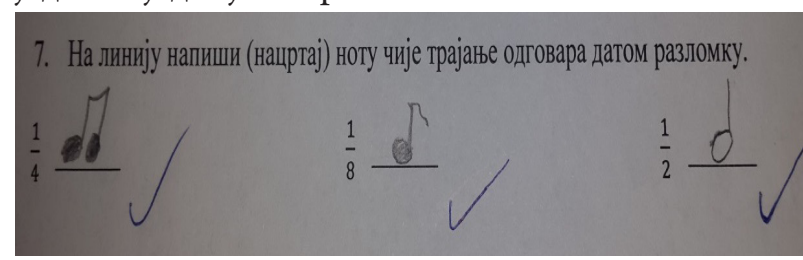

Слика 6. Тачан и јеgинсиивен оgі̄овор ученика у 7.

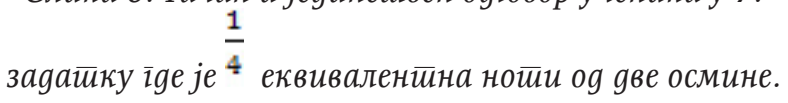

Као одговор се очекивала нота •, али с обзиром на то да су две осмине једнаке једној четвртини по трајању, одговор се са задовољством прихватио, а ученик је додатно показао да разуме односе нотних трајања/разломака.

Продискутујмо и о осмом задатку (финални тест, Прилог 2), у ком је путем дужи као модела за означавање тактова требало да се представе и разломком означе делови такта. Ниједан ученик из контролне групе није дао тачан одговор, а седамнаест ученика $(29,8 \%)$ из експерименталне групе је дало тачан одговор на овај захтев (Табела 3), где је потврђено да је експериментална група била статистички значајно успешнија $(\mathrm{t}=4,26, \mathrm{df}=111, \mathrm{p}>0.01)$. Неке од типичних грешака у обе групе, а посебно у контролној групи, јесу те да су део дужи који одговара трећем такту уместо са $\frac{1}{7}$ означавали са $\frac{1}{3}$, вероватно зато што је у питању трећи такт, стога нису добро сагледали однос дела према целини (Слика 7a); нису уочили да су други и четврти такт једнаки (исти); нису означавали дуж тачкама на крају, па су добијали праву (Слика 7б); нису обележавали дуж словима (Слика 7в); нису једнако делили дуж (Слика 7г).

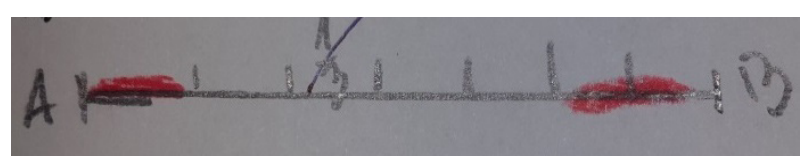

$7 a$

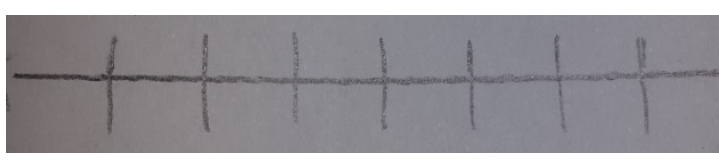

$7 b$

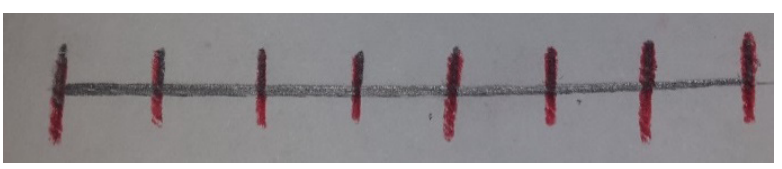

$7 v$

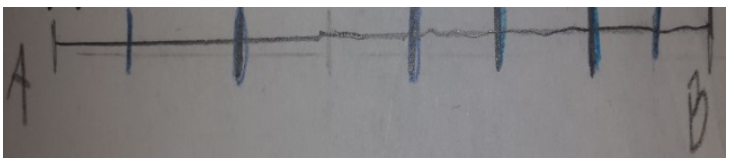

$7 g$

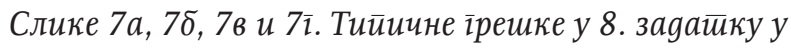

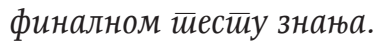

Наведено сматрамо великим грешкама, с обзиром на то да се дуж ради од првог разреда, а у наредним разредима се утврђује. Овим задатком хтели смо да проверимо каква су знања ученика када је у питању дуж, као и тактови. С обзиром на то да је проценат тачно урађених захтева у овом задатку низак, сматрамо да, уколико би се повремено повезивали садржаји, као што је урађено у овом задатку, истовремено могло проверити знање из обају наставних предмета, јер им овакав начин може бити интересантнији, али и сложенији, чиме би развијали логичко мишљење.

И на крају, продискутујмо и о деветом задатку (финални тест, Прилог 2), где је шест ученика $(10,7 \%)$ из контролне групе и тридесет ученика (52,6\%) из експерименталне групе одговорило тачно (Табела 2). Уочено је да је експериментална група показала статистички значајну разлику по успешности у односу на контролну групу $(\mathrm{t}=3,73, \mathrm{df}=111, \mathrm{p}>0.01)$. 
Табела 2. Тачни оgі̄овори ученика обеју іруйа на финалном йестиу из заgайака са йовезивағем саgржаја.

\begin{tabular}{|c|c|c|c|}
\hline & \multicolumn{3}{|c|}{ Редни број задатка } \\
\hline & 7. & 8. & 9. \\
\hline Контролна група $\mathrm{N}$ & 17 & 0 & 6 \\
\hline $\mathrm{f}$ & $30,4 \%$ & $0 \%$ & $10,7 \%$ \\
\hline Експериментална N & 40 & 17 & 30 \\
\hline група & $70,2 \%$ & $29,8 \%$ & $52,6 \%$ \\
\hline
\end{tabular}

$\mathrm{N}$ - број ученика; $\mathrm{f}$ - проценат

У овом задатку је требало да нацртају одређено нотно трајање које одговара дужини дужи (и броју милиметара), као што је показано у првом примеру. Деветнаест ученика $(33,9 \%)$ контрппне групе је поистоветило .. (две осмине) са •• (две четвртине) (Слика 8).

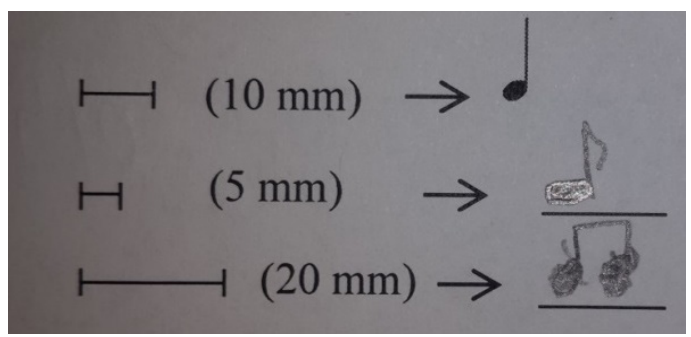

Слика 8. Грешка у 9. заяайку і̄ge је умесйо о їоварано са..

Дакле, ихко се као одговор очекивала једна половина (॰), две четвртине су такође прихватљиве, јер трају дупло дуже од једне четвртине. Овде се показала слаба припремљеност ученика контролне групе из музичке културе, вероватно јер приказане ноте личе, али немају једнако трајање. Указали бисмо на још један пример, у ком је једанаест ученика (19,6 \%) контролне групе уписало ноту која не постоји у мугчци, а представља комбинацију половине ноте 0 и осмине ноте .', што опет приписујемо слабој припремљености ученика контролне групе из музичке културе (Слика 9).

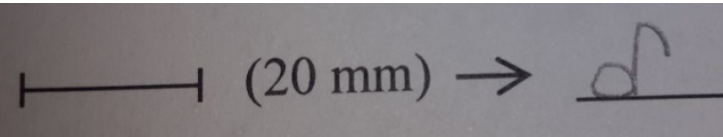

Слика 9. Нейравилно найисана нойа ко у ученика

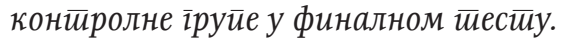

На основу приказаних резултата потврђена је општа хипотеза да су ученици експерименталне групе (статистички) успешнији од ученика контролне групе када су у питању задаци који се тичу повезивања садржаја математике и музичке културе, као и из музичких задатака.

\section{Закључак}

Од учитељеве стручности, креативности и начина рада зависи мотивисаност ученика да различите наставне предмете посматрају као систем. Уместо да памте чињенице, ученике треба упућивати да постављају питања и сами истражују, да примењују своје знање (Loepp, 1999) и сагледавају повезаност на местима где је то смислено, како унутар једног предмета, тако и међу више наставних предмета (Coxford, 1995; Nagel, 2003), негујући на тај начин повезаност математичког мишљења и природе уметности. Музичке активности и садржаји имплементирани у математику стварају услове у којима ученици долазе до суштинског разумевања појмова који су међусобно еквивалентни, чиме се потпомаже изградња појмова у обама наставним пред- 
метима и тиме обогаћују садржаји. Овим путем се код ученика повећава заинтересованост за учење, побољшавају математичка и музичка знања и постигнућа (Song et al., 2013) и омогућава им се да буду активни учесници у настави (Geist et al., 2012). Међутим, међупредметно повезивање треба да има тенденцију ка узајамном допуњавању и не треба на све могуће начине тражити везе (Šulentić Begić, Begić, 2013), већ само на местима где је то смислено и корисно.

Споменули бисмо да суштинско преплитање разломака и трајања тонова и песме које као активности доприносе усвајању математичких појмова треба искористити у процесу изграђивања знања из обају наставних предмета јер, као што смо нашим ефектом показали, ученицима бива лакше да савладају поменуте садржаје (ставићемо акценат на повезаност разломака и тонских трајања), а настава добија нови смисао у ком су ученици заинтересовани да уче нешто ново и истовремено имају могућност да примене знања из различитих предмета. Истра- живања која смо навели у теоријском делу су показала исти резултат - применом и повезивањем математичких и музичких знања ученици успешније савладавају садржаје и лакше долазе до резултата, притом бивајући мотивисанији за рад. Али, како Зечевић истиче, не можемо од ученика да очекујемо да сами примењују математичка знања, већ им треба то сугерисати и учити их смисленој примени садржаја који суштински могу да се повежу са музиком (Zečević i sar., 2014). Дакле, треба размишљати у правцу проналажења математичких и музичких садржаја који имају додирних тачака ради разбијања монотоније и „зидова“ који су постављени између ових двају наставних предмета. Јер баш у том, истовремено и сложеном и лепом, сусретању ових двају наставних предмета налазе се велике могућности за обликовање наставних садржаја примерених узрасту нижих разреда основне школе, стога указујемо да треба покушати спојити рационално и емоционално у јединствену целину.

\section{Литература}

- Andrić, V., Spasojević, P. (2012). Korelacija nastave matematike i ostalih nastavnih oblasti u mlađim razredima osnovne škole. U: Vulović, N. (ur.). Metodički aspekti nastave matematike II (199-212). Jagodina: Fakultet pedagoških nauka.

- Barry, N. H. (2008). The Role of Integrated Curriculum in Music Teacher Education. Journal of Music Teacher Education. 18 (1), 28-38.

- Berke, M. (2000). Curriculum Integration: A two-way street. General Music Today. 14 (1), 9-12.

- Biočić, A. (2015). Primjena korelacije u nastavi glazbene kulture (master rad). Split: Filozofski fakultet.

- Courey, S., Balogh, E., Siker, J. and Paik, J. (2012). Academic music: Music instruction to engage third-grade students in learning basic fraction concepts. Educational Studies in Mathematics. 81 (2), 251-278. Retrieved November 7, 2017. from: https://www.jstor.org/stable/23254240?seq=1\#page_scan_tab_contents

- Coxford, A. F. (1995). The Case for Connections. In: House, P. A. \& Coxford, A. F. (Eds.). Connecting mathematics across the curriculum (3-12). Reston, Virginia: National Council of Teachers of Mathematics.

- Culek, I. (2015). Glazba i matematika (diplomski rad). Osijek: Sveučilište Josipa Jurja Strossmayera.

- David Jr., J. H. (1995). The Mathematics of Music. Retrieved May 2, 2017. from: http://jackhdavid. thehouseofdavid.com/papers/math.html.

- Dejić, M., Mihajlović, A. (2014). Matematička darovitost. Beograd: Učiteljski fakultet. 
- Diefes-Dux, H. A., Whittenberg, L. \& McKee, R. (2013). Mathematical Modeling at the Intersection of Elementary Mathematics, Art and Engineering Education. In: English, L. \& Mulligan, J. (Eds.). Reconceptualizing Early Mathematics Learning (309-325). Dordrecht: Springer Science + Business Media Dordrecht.

- Đokić, O. (2007). Pojam linije u početnoj nastavi geometrije. Beograd: Učiteljski fakultet.

- Geist, K., Geist, E. A. \& Kuznik, K. (2012). Young Children Learning Mathematics through Beat, Rhythm, and Melody. Young Children. 67 (1), 74-79.

- Gnjidić, G. (2014). Zanimljiva veza matematike i muzike. Posećeno 27. 4. 2017. na: https://goranagnjidicmath. wordpress.com/2014/09/29/veza_matematike_i_muzike/.

- Grandin, T., Peterson, M. \& Shaw, G. L. (1988). Spatial-temporal versus language-analytic reasoning: The role of music training. Arts Education Policy Review. 99 (6), 11-15.

- Hurić, Z. (2014). Korelacija matematike i ostalih nastavnih predmeta. Nastava matematike. 59 (4), 41-44.

- Johnson, G. \& Edelson, J. (2003). Integrating Music and Mathematics in the Elementary Classroom. Teaching children mathematics. 9 (8), 474-479.

- Jović Miletić, A. (2008). Tonske osnove srpskog muzičkog nasleđa. Knjaževac: Nota.

- Kells, D. (2008). The Impact of Music on Mathematics Achievement. Retrieved May 11, 2017. from: http:// www.susi-up.de/wp-content/uploads/2010/04/ImpactOfMusicOnMath.pdf.

- Loepp, F. L. (1999). Models of curriculum integration. The Journal of Technology. 25 (2), 1-7.

- Maričić, S., Ćalić, M. (2015). Integracija razvoja matematičkih pojmova i muzičkog vaspitanja u predškolskom vaspitanju i obrazovanju posredstvom pesama za pevanje. U: Denić, S. (ur.). Godišnjak Učiteljskog fakulteta u Vranju (317-326). Vranje: Učiteljski fakultet.

- Nagel, N. G. (2003). Connecting through Integrated Mathematics. In: McGraw, S. A. (ed.). Integrated Mathematics: Choices and Challenges (177-188). Reston, Virginia: National Council of Teachers of Mathematics.

- Savić, J. (2016). Korelacija misaonih aktivnosti učenika u nastavi matematike i muzičke kulture u mlađim razredima osnovne škole (master rad). Beograd: Učiteljski fakultet.

- Scripp, L. (2000). Introduction: the premise of learning through music. Retrieved May 13, 2017. from: http://s3.amazonaws.com/academia.edu.documents/40644725/INTRODUCTION_THE_PREMISE_OF_ LEARNING_THR20151204-2677-19mm1i8.pdf?AWSAccessKeyId=AKIAIWOWYYGZ2Y53UL3A\&Expir es $=1498496488 \&$ Signature $=$ UmJ9okKcXEATIpb3XzYdpVXeWc0\%3D\&response-content-disposition $=$ inli ne\%3B\%20filename\%3DINTRODUCTION_THE_PREMISE_OF_LEARNING_THR.pdf.

- Shah, S. (2010). An Exploration of the Relationship between Mathematics and Music. Manchester: Manchester Institute for Mathematical Sciences.

- Song, A., Capraro, M. M. \& Tillman, D. A. (2013). Elementary Teachers Integrate Music Activities into Regular Mathematics Lessons: Effects on Students' Mathematical Abilities. Retrieved October 19, 2017. from: https:// escholarship.org/uc/item/0js732gf.

- Stojanović, A. (2014). Korelacija u nastavi. U: Leksikon obrazovnih termina (332-333). Beograd: Učiteljski fakultet. 
- Šulentić Begić, J., Begić, A. (2013). Mogućnosti interdisciplinarnog povezivanja nastave glazbe s neglazbenim predmetima. U: Vidulin-Orbanić, S. (ur.). Interdisciplinarni pristup glazbi: istraživanje, praksa i obrazovanje. Glazbena pedagogija u svijetu sadašnjih i budućih promjena 3 (241-256). Treći međunarodi simpozij glazbenih pedagoga, 18-20. 4. 2013. Pula: Sveučilište Jurja Dobrile, Odjel za glazbu.

- Whitwell, D. (2011). Foundations of Music Education. Austin, Texas: Whitwell Books.

- Zečević, I., Mikanović, B., Hadžić, A. i Drobac, M. (2014). Znanja i vještine u nastavnim programima za mlađi školski uzrast. Inovacije u nastavi. 27 (2), 84-94.

\section{Извори}

- Nastavni program obrazovanja i vaspitanja za treći razred osnovnog obrazovanja i vaspitanja (2012). Zavod za unapređivanje obrazovanja i vaspitanja.

- Stojanović, G., Vasiljević, Z. (2013). Muzička kultura za 2. razred osnovne škole. Beograd: Zavod za udžbenike i nastavna sredstva. 
Прилог 1. Иницијални тест знања

Драги учениче,

Пред тобом се налазе задаци из математике и музичке културе које треба да решиш. Пажљиво читај задатке. За рад је предвиђен један школски час. Унапред хвала на твом труду.

1. Повежи дате разломке са одговарајућим сликама

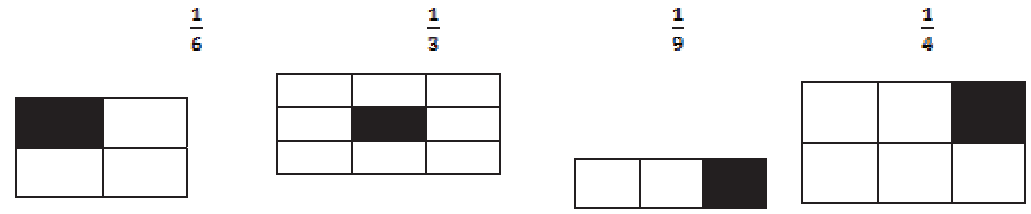

2. Реши једначине:
a) $x+687=948$
б) $x-322=419$

3. Повежи паузе са одговарајућим нотним трајањима.

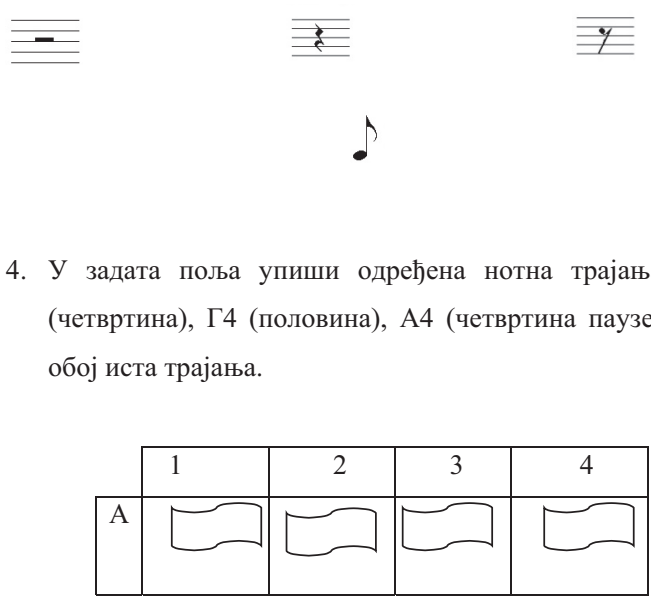




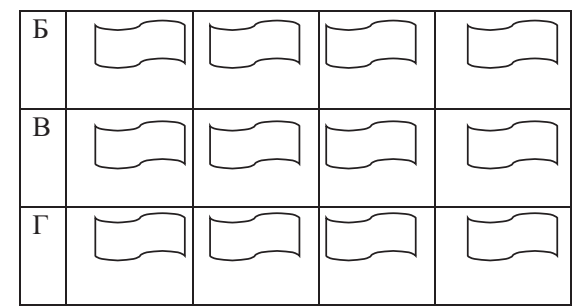

5. На следећој слици допуни тактове тако да у сваком вагону буде тачна једнакост у односу на врсту такта (у локомотиви). Односи трајања у сваком вагону морају одговарати врсти такта/мери. Користи различита трајања која си научио/ла.
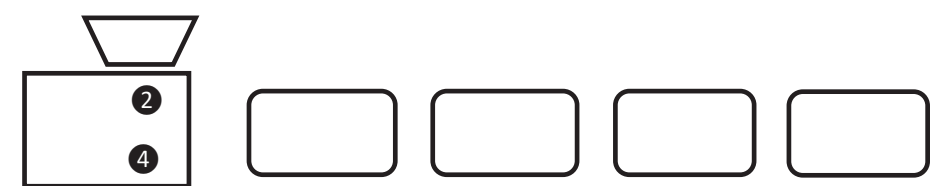

6. Користећи знања о упоређивању (бројева), упиши одговарајуће ноте на линије.

Нота за 2 (степена) виша од ми је

Нота за 1 мања (нижа) од си је

Нота између ре и фа је

4. нота у C-dur лествици је

Нота за 3 виша од фа је

Нота која је за 4 мања (нижа) од ноте која је за 1 виша од сол је

Нота која је најнижа од свих других, а припада C-dur-y je

6. Нацртај дуж чија је дужина 12 цм и обележи је. Једном бојом означи на дужи њену половину, а другом бојом њену четвртину. Изнад свих делова дужи запиши разломцима које делове дужи означавају. 
7. Ако је четвртина ноте једнака дужи од 10 мм, нацртај дужи (и напиши колико имају милиметара) као што је започето. Дужи треба да одговарају трајањима тонова.

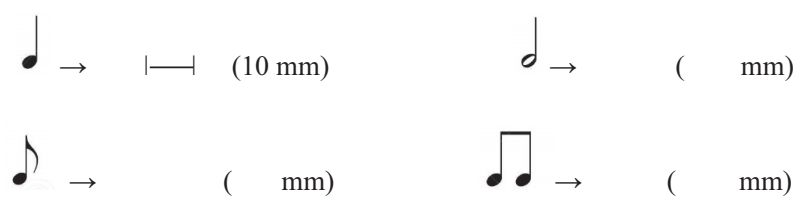

\section{Прилог 2. Финални тест знања}

Драги учениче,

Пред тобом се налазе задаци из математике и музичке културе које треба да решиш. Пажљиво читај задатке. За рад је предвиђен један школски час. Унапред хвала на твом труду. Срећан рад!

1. Реши једначине:
a) $x+859=1754$
б) $2374-\mathrm{x}=767$

2. Повежи ноте које имају једнака трајања.

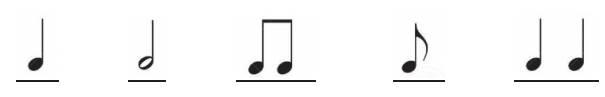

3. Нацртај дуж од $9 \mathrm{~cm}$ и обележи је. Црвеном бојом означи на дужи једну деветину, а зеленом четири деветине и запиши разломцима изнад дужи. 
4. Повежи слике са одговарајућим разломцима. Разломак који је остао неповезан повежи са одговарајућом сликом коју ћеш нацртати (и осенчити потребне делове).
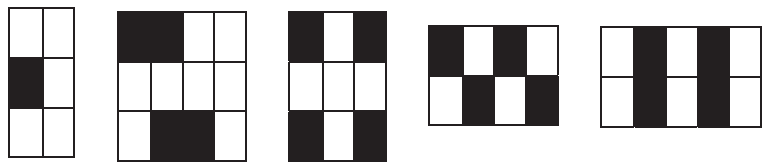

$\frac{1}{3} \quad \frac{1}{6} \quad \frac{2}{5}$

5. У празне кругове допиши ноте у складу са захтевима испод нотног записа.

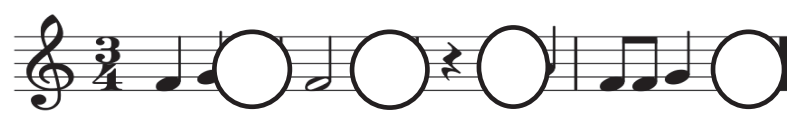

У први круг упиши (нацртај) ноту која је за 3 ноте виша од ми.

У други круг упиши ноту која је за 2 ноте нижа од ла.

У трећи круг упиши ноту која се налази између нота ре и фа.

У четврти круг упиши ноту која је за пет нижа од ноте која је за два виша од сол.

6. Попуни линијски систем тако да:

а) такт буде двочетвртински (упиши у круг)

б) имаш 4 такта

в) користиш различита нотна трајања и паузе.

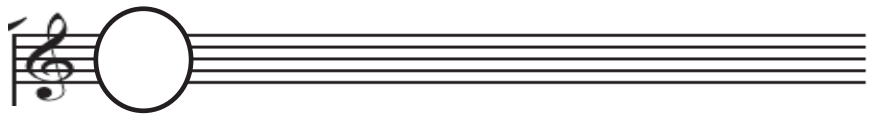


7. На линију напиши (нацртај) ноту чије трајање одговара датом разломку.

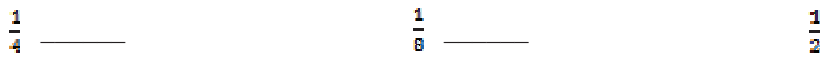

13

8. Дат је нотни запис песме „У Ивана господара“.

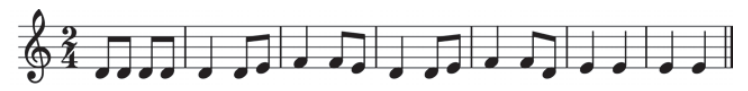

a) Нацртај дуж коју ћеш поделити на онолико једнаких делова колико песма има тактова. Означи ту дуж.

б) Обој истом бојом делове дужи којима одговарају тактови у којима се појављују ноте истих висина и трајања.

в) Пронађи део дужи који одговара трећем такту и напиши разломком изнад који део дужи означава.

9. Ако дуж од 10 мм одговара четвртини ноте, упиши одговарајућа трајања тонова (ноте) у складу са нацртаним дужима (као што је започето).

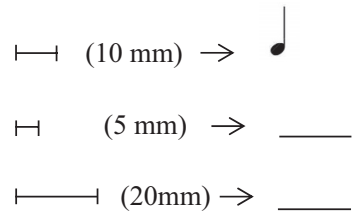




\section{Summary}

The content of the paper is focused on determining the efficiency of an experimental program based on linking mathematics and music content in order to manage the material in both subjects better in the lower grades of elementary school. Contemporary teaching aims at linking the contents of different subjects to make pupils' knowledge more lasting and teaching more effective. In this paper, we will point out the contents of mathematics in which it is possible to implement music teaching content and vice versa in order to improve the cognitive development of children of the lower school age. The aim of the research is the experimental study of the effects of a teaching approach in which the teaching contents of mathematics and music are linked. An experimental method was used, based on which we obtained the basic result that the knowledge of fractions is helpful in learning the tone duration (and vice versa). Given that we also observed a poor knowledge of the basic elements of musical literacy among students, we emphasize the possibility of improving students' learning motivation by applying the mathematics contents that are essentially related to specific music contents.

Keywords: lower grades of elementary school, mathematics teaching, music teaching, interconnectedness of mathematics and music teaching content. 